\title{
Bir Tıp Fakültesi Hastanesi Sağlık Çalışanlarında Hepatit A, Hepatit B, Hepatit C Seroprevelansı ve Aşılanma Durumu
}

\author{
Hepatitis A, Hepatitis B, Hepatitis C Seroprevalence and Vaccination Status of Health \\ Providers in an University Hospital \\ Hasan Apaydın', Şevin Demir ${ }^{1}$, Aslı Karadeniz ${ }^{2}$ \\ ${ }^{1}$ Maltepe Üniversitesi Tip Fakültesi Hastanesi, Aile Hekimliği Anabilim Dalı, İstanbul \\ ${ }^{2}$ Maltepe Üniversitesi Tip Fakültesi Hastanesi, İnfeksiyon Hastalıkları ve Klinik Mikrobiyoloji Anabilim Dal, İstanbul.
}

\begin{tabular}{|c|}
\hline $\begin{array}{l}\text { Yazışma Adresi / Correspondence: } \\
\text { Şevin Demir }\end{array}$ \\
\hline Maltepe Üniversitesi Tip Fakültesi Hastanesi, Feyzullah Cad. No: 39, İstanbul \\
\hline T: + $905335955579 \quad$ E-mail : sevin.demir@maltepe.edu.tr \\
\hline Geliş Tarihi / Received : 05.10.2020 Kabul Tarihi / Accepte: 03.04.2021 \\
\hline Orcid : \\
\hline Hasan Apaydın https://orcid.org/0000-0003-1367-1850 \\
\hline Şevin Demir https://orcid.org/0000-0002-9541-5676 \\
\hline Aslı Karadeniz https://orcid.org/0000-0003-3799-1090 \\
\hline
\end{tabular}

\footnotetext{
$\ddot{\mathrm{O} z}$

Amaç Sağlık çalışanları enfeksiyon hastalıkları açısından yüksek risk altındadır. Bu çalışmada, bir üniversite hastanesindeki sağlık çalışanlarında, hepatit A, hepatit B, hepatit C virüsü(HAV, HBV, HCV) ve insan immun yetmezlik virüsü (HIV) seroprevalansının araștırılması amaçlanmıştır.

Gereç ve Maltepe Üniversitesi Tip Fakültesi Hastanesỉnde hastane çalışanlarına 01.01.2020-01.07.2020 tarihleri arasında yapılan periyodik muayene formlarında bulunan hepatit Yöntem virüs ve HIV serolojileri ve hepatit A ve B enfeksiyonları için aşılanma durumları değerlendirilmiştir.

Bulgular Çalışmaya 375 sağlık personeli (\%71,20 kadın, \%28,80 erkek) dahil edilmiştir. Çalışanların yaş ortalaması 32,92 99,58 idi. Anti-HAV IgG pozitifliği tüm personelde\%58.80 saptandı, büyük yaş gruplarında bağıșıllık artıșı istatistiksel olarak anlamlı idi ( $\mathrm{p}<0,001)$. HBsAg pozitifliği $\% 0,30$ anti-HBs pozitifliği \%84 saptandı. Yaş grupları arasında anti-HBs pozitifliği istatistiksel açıdan anlamlı olarak farklı saptandı $(\mathrm{p}<0.001)$.

Sonuç Hepatit bulaşını azaltmada evrensel önlemlere uyum esastır. Aşıyla önlenebilen hepatit etkenlerine karşı bağışılık tüm sağlık çalışanlarında taranarak, bu enfeksiyonlara duyarlı olan bireyler aşılanmalıdır.

Anahtar hepatit A; hepatit B; hepatit C; sağlık çalışanları

Kelimele

Abstract

Objective Health providers at high risk of infectious diseases. The aim of this study was to determine the seroprevalence of hepatitis A, hepatitis B, hepatitis C and human immunodeficiency virus (HIV) among health providers in a state hospital.

Materials Hepatitis virus and HIVserologies and vaccination status for hepatitis A and B infections on the periodic examination forms between 01.01.2020-01.07.2020 were examined for hospital staff and methods at Maltepe University Medical Faculty Hospital.

Results 375 health providers were included in the study, $71.20 \%$ participants were female and $28.80 \%$ were male. The average age of the participants is $32.92 \pm 9,58$. Anti HAV IgG positivity rates were determined to be $58.80 \%$. Anti-HAV IgG positivity was found to increase with age ( $p<0.001)$. HBsAg positivity was determined $0.30 \%$, and Anti-HBs positivity was $84 \%$. Anti-HBs positivity was found to be different between age groups $(P<0.001)$.

Conclusion Compliance with universal measurements is essential in reducing hepatitis transmission. Immunity against vaccine-preventable hepatitis factors should be screened in all healthcare workers and individuals susceptible to these infections should be vaccinated.

Keywords hepatitis A; hepatitis B; hepatitis $C$; health providers
} 


\section{GIIRIŞ}

Hepatit B virüsü (HBV), hepatit $C$ virüsü (HCV), hepatit A virüsü (HAV) ve insan immun yetmezlik virüsü (HIV) enfeksiyonları gibi bulaşıcı hastalıklar tüm dünyada sürekli artan hasta sayılarına bağlı olarak büyük bir sağlık sorunu oluşturmaktadır. Dünya Sağlık Örgütü (DSÖ) verilerine göre 2015 yılında dünya genelinde tahmini 257 milyon kronik HBV taşıyıcısı bulunmaktadır ve bunlardan sadece \%10 kadarı taşıyıcı olduklarının farkındadır, yine DSÖ verilerine göre 2019 yılında dünya genelinde yaklaşık 79 milyon HCV taşıyıcısı bulunmaktadır ve sadece 2016 yılında tahmini olarak 399 bin kişi Hepatit C ve komplikasyonları nedeniyle hayatını kaybetmiştir. Ayrıca 38 milyon HIV taşıyıcısı olduğu tahmin edilmektedir. Hepatit A nedeniyle ise sadece 2016 yılında 7134 kişi hayatını kaybetmiştir. ${ }^{1}$

Meslek gereği farkında olmadan ya da olarak bu hastalıkları taşıyan kişilerle iç içe oldukları için sağlık çalışanları büyük risk altındadır. Enfekte kesici delici alet yaralanmalarında enfekte olma riski HIV için \%0,23 iken; HCV için \%1-3 ve HBV için ise \%30'lara kadar çıkmaktadır. ${ }^{2,3}$ Kesici ve delici alet yaralanmalarından dolayı her yıl yaklaşık 16 bin sağlık çalışanı Hepatit C ile enfekte olmakta, bunların 142 tanesi ölümle sonuçlanmakta ve 66 bin sağlık çalışanı ise aynı nedenden Hepatit B ile enfekte olmakta ve 261'i ölümle sonuçlanmaktadır. ${ }^{4}$

Kesici delici alet yaralanmalarına ek olarak, vücut sıvıları ile temas (göz, burun, ağız gibi organlara sıvı teması, deri bütünlüğü bozulmuş olan dokulara temas), inhalasyon gibi bulaş yolları da eklenince sağlık çalışanları açısından bulaş riski oldukça artmaktadır. Bu nedenden dolayı, sağlık eğitimi almış olsun veya olmasın, hastanede çalışan ve hasta ile teması olan herkes bulaş riskine karşı el yıkama, maske ve eldiven kullanımı, gerekli durumlarda gözlük kullanımı gibi standart önlemler almanın yanı sıra aşı ile önlenebilen enfeksiyon hastalıkları açısındanaşılarını da yaptırarakbulaş riskini en aza indirmelidir. Ülkemizde HBV ve HAV aşıları sağlık çalışanları için önerilen aşılar arasindadir. $^{5}$
Bu çalışmada; T.C. Maltepe Üniversitesi Hastanesinde çalışan sağlık çalışanlarının hepatit $\mathrm{A}$, hepatit $\mathrm{B}$, hepatit $\mathrm{C}$, HIV yönünden serolojik taranması ve aşı ile korunabilen hastalıklardan olan hepatit B ve hepatit A ya karşı aşılanma durumlarının araştırılması amaçlanmıştır.

\section{Gereç ve Yöntemler}

Maltepe Üniversitesi Tip Fakültesi Hastanesi'nde hastane çalışanlarına 01.01.2020-01.07.2020 tarihleri arasında yapilan periyodik muayene formları retrospektif olarak incelenerek yapılmıştır. Formlarda bulunan yaş, cinsiyet, çalıştığı bölüm, meslek, boy, kilo verileri ile serolojik testlerin sonuçları (anti-HAV IgG, HbsAg, anti-HBs, anti-HCV, anti-HIV değerleri) ve hepatit $\mathrm{A}$ ve $\mathrm{B}$ enfeksiyonları için aşılanma durumları kaydedilmiştir. Serum örnekleri kemilüminesans esasına dayanan makro "enzyme-linked immunosorbent assay" (ELISA yöntemi) ile analiz edilmiş, anti-HAV IgG pozitifliği ( $\geq 20 \mathrm{IU} / \mathrm{mL}$ ) ve anti-HBs pozitifliği ( $\geq 10 \mathrm{IU} / \mathrm{mL}$ ) olan çalışanlarda aşılama durumu sorgusu ile bağışıklık yolu değerlendirilmiştir. HBsAg ve anti-HCV pozitif olan sağlık çalışanları alınan kan numunelerinde RT-PCR yöntemiyle HBV-DNA ve HCV-RNA tetkiki ile pozitiflik durumunda, takip ve tedavi için enfeksiyon hastalıkları polikliniğine yönlendirilmiştir.

Maltepe Üniversitesi Klinik Araştırmalar Etik Kurulunun 08.05.2020 tarih ve 2020/900/28 sayılı izni ile çalışmaya başlandı. Çalışmada Helsinki Deklerasyonuna uyuldu.

Elde edilen veriler SPSS-24 istatistik paket programı kullanılarak değerlendirilmiştir. Tanımlayıcı istatistikler sayı (n), yüzde (\%), aritmetik ortalama, standart sapma olarak belirtilmiştir. Sayısal verilerin karşılaştırılmasında tek yönlü varyans analizi (oneway ANOVA) ve ki-kare testleri kullanılmıştır. Sonuçlar \%95 güven aralığında değerlendirilmiş olup $\mathrm{p}<0.05$ değeri istatistiksel anlamlı kabul edilmiştir.

\section{BULGULAR}


Çalışmaya 267'si kadın 88'i erkek olmak üzere 375 sağlık çalışanı dahil edilmiştir. Çalışanlarımız doktor, hemşire ve ilk iki gruba girmeyen diğer çalışanlarımız olarak 3 mesleki gruba ayrılmıştır. Mesleki gruplar arası yaş, cinsiyet, vücut kütle indeksi(VKİ) arasında istatistiki olarak anlamlı fark saptanmıştır (Tablo 1).

\begin{tabular}{|l|c|c|c|c|}
\hline \multicolumn{4}{|c|}{ Tablo 1: Meslek gruplarına göre demografik özellikler } \\
\hline & Doktor & Hemşire & $\begin{array}{c}\text { Yardımc1 } \\
\text { Sağllk } \\
\text { Personeli }\end{array}$ & \\
\cline { 2 - 5 } & $(\mathrm{n}=43)$ & $(\mathrm{n}=158)$ & $(\mathrm{n}=174)$ & \\
\hline Yaş (yll) & $41,33 \pm 9,90$ & $28,28 \pm 7,50$ & $35,06 \pm 8,90$ & $\mathrm{P}<0.001$ \\
\hline $\begin{array}{l}\text { Cinsiyet } \\
\text { (K/E) }\end{array}$ & $22 / 21$ & $121 / 37$ & $124 / 50$ & $\mathrm{P}=0.005$ \\
\hline $\begin{array}{l}\text { VKİ (kg/ } \\
\text { m2) }\end{array}$ & $24,57 \pm 3,14$ & $23,31 \pm 3,54$ & $24,65 \pm 4,46$ & $\mathrm{P}=0.006$ \\
\hline VKİ: Vücut Kütle İndeksi & & & \\
\hline
\end{tabular}

Anti-HCV ve HbsAg değeri pozitif çıkan 3 çalışanımız takip ve tedavi edilmesi amacıyla enfeksiyon hastalıkları polikliniğine yönlendirilmiştir (Tablo 2).

\begin{tabular}{|l|c|c|c|}
\hline \multicolumn{4}{|c|}{ Tablo 2: Mesleki gruplara göre viral hepatit serolojisi } \\
\hline Pozitiflik (\%) & Doktor (n=43) & $\begin{array}{c}\text { Hemşire } \\
(\mathrm{n}=158)\end{array}$ & $\begin{array}{c}\text { Yardımcı Sağllk } \\
\text { Personeli } \\
(\mathrm{n}=174)\end{array}$ \\
\hline $\begin{array}{l}\text { Anti HAV IgG } \\
(58.8)\end{array}$ & $\begin{array}{c}\% 64,30 \\
(\mathrm{n}=27)\end{array}$ & $\begin{array}{c}\% 61,80 \\
(\mathrm{n}=97)\end{array}$ & $\begin{array}{c}\% 54,70 \\
(\mathrm{n}=94)\end{array}$ \\
\hline HbsAg (0.3) & 0 & 0 & $\begin{array}{c}\% 0,57 \\
(\mathrm{n}=1)\end{array}$ \\
\hline AntiHBs (84) & $\begin{array}{c}\% 97,70 \\
(\mathrm{n}=42)\end{array}$ & $\begin{array}{c}\% 99,40 \\
(\mathrm{n}=157)\end{array}$ & $\begin{array}{c}\% 66,70 \\
(\mathrm{n}=116)\end{array}$ \\
\hline $\begin{array}{l}\text { Anti HCV } \\
(0.5)\end{array}$ & $\begin{array}{c}\% 4.65 \\
(\mathrm{n}=2)\end{array}$ & 0 & 0 \\
\hline
\end{tabular}

İki doktorumuzun HCV-RNA değerleri negatif gelirken, HbsAg pozitif gelen çalışanımız takibe alınmıştır. Bütün çalışanımızın anti-HIV değerleri negatif bulunmuştur. Çalışanlarımızın HAV ve HBV bağışıklık durumu (seropozitifliği) ve sorgulanan aşılanma durumları Tablo-3 ve Tablo-4 de sunulmuştur. Tüm çalışanlarda HAV seropozitifliği $\% 58.80$, anti-HBs pozitifliği \%84 oranında bulunmuştur. Yaş gruplarına göre değerlendirildiğinde, HAV ve HBV bağışıklık oranlarında istatistiksel olarak anlamlı fark saptanmıştır (Tablo 5).

\begin{tabular}{|c|c|c|c|c|c|c|}
\hline \multirow{3}{*}{ Anti-HAV IgG } & \multirow{2}{*}{\multicolumn{2}{|c|}{$\begin{array}{l}\text { Doktor } \\
(\mathrm{n}=43) \\
\end{array}$}} & \multirow{2}{*}{\multicolumn{2}{|c|}{$\begin{array}{l}\text { Hemşire } \\
(n=158)\end{array}$}} & \multirow{2}{*}{\multicolumn{2}{|c|}{ Yardımcı Sağlık Personeli $(\mathrm{n}=174)$}} \\
\hline & & & & & & \\
\hline & $\mathrm{K}(\mathrm{n}=14)$ & $E(n=13)$ & $\mathrm{K}(\mathrm{n}=78)$ & $E(n=19)$ & $K(n=69)$ & $E(n=25)$ \\
\hline Doğal bağışık & 57,10 & 100 & 48,70 & 23,70 & 21,70 & 48 \\
\hline Așill & 42,90 & 0 & 51,30 & 26,30 & 78,30 & 52 \\
\hline
\end{tabular}

\begin{tabular}{|c|c|c|c|c|c|c|}
\hline \multirow{3}{*}{ Anti-HBs } & \multirow{2}{*}{\multicolumn{2}{|c|}{$\begin{array}{l}\text { Doktor } \\
(n=43)\end{array}$}} & \multirow{2}{*}{\multicolumn{2}{|c|}{$\begin{array}{l}\text { Hemşire } \\
(\mathrm{n}=158)\end{array}$}} & \multirow{2}{*}{\multicolumn{2}{|c|}{ Yardımcı Sağlık Personeli $(\mathrm{n}=174)$}} \\
\hline & & & & & & \\
\hline & $K(n=22)$ & $E(n=20)$ & $\mathrm{K}(\mathrm{n}=121)$ & $E(n=36)$ & $\mathrm{K}(\mathrm{n}=74)$ & $\mathrm{E}(\mathrm{n}=41)$ \\
\hline Doğal bağışık & 9,10 & 0 & 8,30 & 16,70 & 23 & 29,30 \\
\hline Aşıllı & 90,90 & 100 & 91,70 & 83,30 & 77 & 70,70 \\
\hline
\end{tabular}

\begin{tabular}{|l|c|c|c|c|c|}
\hline Tablo 5:Anti HAV-IgG ve Anti-HBs pozitifliklerinin yaş gruplarına göre dağılımları \\
\cline { 2 - 6 } & $18-25$ yaş & $26-35$ yaş & $36-45$ yaş & $>45$ yaş & \\
\cline { 2 - 6 } & $(\mathrm{N}=103)$ & $(\mathrm{n}=138)$ & $(\mathrm{n}=90)$ & $(\mathrm{n}=44)$ & $\mathrm{P}<0.001$ \\
\hline Anti-HAV IgG pozitifliği (\%) & 38,20 & 52,20 & 80,90 & 81,80 & $\mathrm{P}<0.001$ \\
\hline Anti HBs pozitifliği (\%) & 100 & 76,10 & 77,80 & 84,10 & \\
\hline
\end{tabular}




\section{Tartışma}

Sağlık çalışanları, hastalarla veya hastaların enfekte kan ve vücut sekresyonları ile direk temasa bağlı olarak, enfeksiyon riski altındadır. Hepatit virüsleri, HIV gibi etkenler sağlık çalışanları için risk oluşturan bu enfeksiyonların önemli kısmını oluşturmaktadır. ${ }^{6-8}$

Ülkemizde toplum geneline oranla biraz daha düşük olmakla birlikte, sağlık çalışanlarında son 10 yıl içinde yapılan çalışmalarda HBV taşıyıcılığı $\% 0,40-1,70$ arasında ve sağlık çalışanlarında anti-HBs pozitifliği \%35-89 arasında saptanmıştır. ${ }^{6-9}$ Daha önceki dönemlerde \%26-50 anti-HBs pozitifliği saptanan çalışmalara göre son 10 yıldaki çalışmalarda anti-HBs pozitifliğinin daha yüksek olması, eğitimlerle farkındalığın artmasına ve aşılama programlarına bağlanmıştır. ${ }^{7}$ Çalışmamızda anti-HBs pozitifliği \% 84 oranında olup, sadece bir çalışanımızda (\%0.30) HBV taşıyıcılığı saptanmıştır. HBV bağışıklığı oranımız; Gülaçtı ve arkadaşlarının çalışmasında saptanan \%35 ve Özgüler M ve arkadaşlarının çalışmasında saptanan \%56.50 gibi oranlara kıyasla daha yüksek, anti-HBs pozitifliğini \%87 civarında saptayan çalışmalarile benzer saptanmıştır.9-12 Sağlık çalışanlarında HBV taşıyıcılığı topluma oranla daha düşük olduğunu gösteren çalışmalarla uyumlu olarak, HBV pozitifliği düşüktür. ${ }^{8,12}$ Sağlık çalışanlarındaki anti-HBs için oranlar literatürle kıyaslandığında, HBV’ye duyarlılığı temizlik personelinde (\%14) daha yüksek saptayan çalışma ile benzer duyarlılık oranımız yanında, bizim çalışmamızda da yardımcı sağlık personelinde anti-Hbs negatifliği daha yüksekti. ${ }^{6}$ HBV bağışıklığını \%96 oranında aşılama ile sağlandığını saptayan Kader Ç ve arkadaşlarının çalışmasına benzer şekilde bizim çalışmamızda da HBV bağışıklığı saptanan personellerin aşılanma öyküsü sorgulandığındaantikor pozitifliğinin yüksek oranda aşılanmaya bağlı olduğu gözlendi. Çalışmamızda, HBV bağışıklığının yüksek oranda aşılanma ile gerçekleşmesi ve aşılanma oranının doktorlarda daha yüksek olması; en yüksek aşılanmanın \%85 oranda doktor grubunda olduğunu belirten çalışma ve doktorlarda aşı ile HBV bağışıklığının (\%97) anlamlı olarak daha yüksek saptandığı çalışma ile benzerlik göstermektedir. ${ }^{7,12}$ Yaş gruplarına göre değerlendirildiğinde, yaş ile anti-HBs pozitifliğinin anlamlı olarak arttığını saptayan Köse ve arkadaşlarının çalışmasından farklı olarak, bizim çalışmamızda 18-25 yaş arasında \%100 pozitifliğin, büyük yaş gruplarında \%77-85 oranına gerilediği saptanmıştır. ${ }^{8}$ Aynı çalışmada doktor ve hemşirelerde (\%85’in üzerinde), diğer sağlık çalışanlarından (\%70 civarında) yüksek olan HBV bağışıklığı, bizim çalışmamızda da doktor ve hemşire grubunda daha yüksek saptanmıştır. ${ }^{8} \mathrm{Bu}$ durum doktor ve hemşire grubunda diğer sağlik çalışanlarından daha fazla olmak üzere, genç çalışanlarda eğitim ve aşılama programlarına katılım ve uyumun fazla olmasına ve günümüzde bu programların öğrencilik döneminde uygulanmaya başlanmasına bağlanmıştır.

Ülkemizdeki çalışmalarda sağlık çalışanlarında HCV prevelansı sıklıkla \%1'in altında (\%0,3 civarında) bulunmuş olup, çalışmamızda da benzer şekilde \% 0.50 saptanmıştır. $^{8,11,13} \mathrm{Bu}$ çalışanlarda HCV-RNA negatif sonuçlanmıştır.

Akut viral hepatitinin önemli etkenlerinden olan HAV, fekal oral yolla bulaşan sanitasyon ve hijyen koşullarında iyileşme gibi nedenlerle bağlı olarak, ülkeden ülkeye değişen seropozitiflik oranları gösteren bir etkendir. Ülkemizde de bölgesel ve yaş gruplarına göre farklı oranlar ve genç yaş gruplarında duyarlılığın arttığı bildirilmektedir ${ }^{10,14}$ Ülkemizde çocukluk çağı aşı takvimine 2012 yılında alınan HAV için dolayısıyla aşılanmamış ve çocuklukta geçirmemiş bireyler için özellikle riskli birimlerdeki sağlık çalışanlarının aşılaması önerilmektedir. ${ }^{8}$ Sağlık çalışanlarındaki HAV seropozitifliği de ülkemizde farklı çalışmalarda özellikle coğrafi bölgelere göre değişkenlik göstermektedir; batı bölgelerde bazı merkezlerde \%10 seropozitiflik bildirilirken, doğu bölgelerde sağlık çalışanlarında \%90 üzerinde pozitiflik bildiren yayınlar bulunmaktadır. ${ }^{10,11,15}$ Bizim çalışmamızda \%58.8 seropozitiflik oranı, İstanbul bölgesinde \%43 saptayan Şahin A. ve arkadaşlarının çalışması ile kıyaslandığımızda biraz yüksek, Eskişehir bölgesindeki \%72 bulunan çalışmada Yozgat bölgesinde \%79 civarında saptanan çalışma ile kıyaslandığında daha 
düşük saptanmıştır. ${ }^{6,8,16}$ Doktorlarda HAV bağışıklığ1 \%75, hemşirelerde $\% 74$ ve yardımcı sağlık personelinde $\% 84$ civarında saptayarak, doktor ve hemşirelerde HAV duyarlılığın anlamlı olarak daha yüksek olduğunu belirten Köse ve arkadaşlarının çalışmasından farklı olarak, HAV bağışıklığı çalışmamızda doktorlarda \%64.30, hemşirelerde $\% 61.80$ ve yardımcı sağlık personelinde $\% 54.70$ oranında saptanmıştır. ${ }^{8}$ Ülkemiz genelinde yaş ile birlikte toplumda seropozitifliğin arttığını gösteren çalışmalar çoğunlukta olmakla birlikte, yaş grupları arasında fark olmadığını belirten çalışmalar da vardır. ${ }^{8}$ Bizim çalışmamızda 18-25 yaş arası \%38 civarı olan HAV bağışıklığı, 35 yaş üzeri grupta \%80'nin üzerindedir ve genç grupta anlamlı olarak seronegatiflik yüksek saptanmıştır. Çocukluk yaş grubu dışında ağır geçen HAV enfeksiyonu için özellikle mesleki risk altında olan duyarlı personelin aşılanması önemlidir.

Sağlık çalışanlarına HIV pozitif hastaların yoğun olduğu birimlerde çalışanlarda bile bulaş ihtimali oldukça düşük olduğu bildirilmektedir. ${ }^{7}$ Ülkemizde yapılan çalışmalardaki ile benzer şekilde çalışanlarda anti-HIV pozitifliği saptanmamıştır. ${ }^{6,9,12}$

Çalışanlarımız bağışıklık durumlarına göre değerlendirilirken, çalıştıkları bölümlere göre ayrıştırılmamış olmaları çalışmamızın kısıtlılığıdır.

Sonuç olarak, sağlık çalışanları kan ve vücut sıvılarıyla bulaş riski varsa eldiven, gözlük, maske, önlük giymek hasta ile temastan önce, sonra ve eldiven çıkardıktan sonra her zaman el hijyeninin sağlanması gibi evrensel önlemler ile korunmanın mümkün olduğu HCV ve HIV gibi hastalıklar ve bu önlemlere ek olarak aşı ile önlenebilen HAV ve HBV açısından risk altındadır. Sağlık çalışanlarının işe girişte taranmaları, mesleki maruziyet riski altında oldukları hastalıklara karşı korunma konusunda eğitilmeleri, aşı ile önlenebilir hastalıklar için duyarlı olduklarına karşı aşılanmaları önemlidir.

\section{Etik Kurul}

Maltepe Üniversitesi Klinik Araştırmalar Etik Kurulunun 08.05.2020 tarih ve 2020/900/28 sayılı izni alınmıştir. 
Sakarya Tip Dergisi 2021;11(2):360-365

APAYDIN ve Ark., Sağlık Çalışanlarında Hepatit Seroprevelansı ve Așlanma

\section{Kaynaklar}

1. World Health Organization. Data and Statistics. (Erișim tarihi: Temmuz-2020, Erișim adresi: http://www.who.int/hiv/data/en/).

2. https://www.cdc.gov/hiv/pdf/workplace/cdc-hiv-healthcareworkers.pdf (Erișim tarihi: Temmuz-2020).

3. Beltrami EM, Williams IT, Shapiro CN, Chamberland ME. Chamberland ME.Risk and management of blood-borne infections in healthcare workers.ClinMicrobiolRev 2000;13:385407.

4. Pruss-Ustun A, Rapiti E, Hutin Y. Sharpsinjuries: Global burden of disease from sharps injuries to healthcare workers. Geneva: World Health Organization; 2003. Environmental Burden of Disease Series, No 3.

5. Sağllk çalışanlarında așılama; EKMUD Erişkin bağışılklama rehberi 2019; s: 104

6. Korkmaz P, Çağlan FÇ, Aykın N, Alpay Y, Güldüren HM, Yaşar ZD, ve ark. Bir Devlet Hastanesindeki Sağllk Çalş̦anlarında Hepatit A, B, C ve HIV İnfeksiyonu Seroprevalansı Klimik Dergisi 2013; 26(2): 64-7

7. Kader C, Balcı M, Erdoğan Y, Göçmen AY, Meșe Üzümveren B, Unsal G, ve ark. Seroprevalences of Hepatitis B, C, HIV and Hepatitis B Vaccination in Healthcare Workers in Bozok UniversityFaculty of Medicine. FLORA 2012;17(3):126-131.

8. Köse H, Temoçin F. İkinci basamak bir devlet hastanesi çalışanlarında hepatit $A, B$ ve $C$ serolojisinin irdelenmesi. Ortadogu Tip Derg 2019; 11(2): 155-160.

9. Gülaçtı U, Üstün C, Arler, Turan M. Elazı̆̆ Harput Devlet Hastanesi Çalısanlarında Hepatit B ve C Seroprevalansi. Konuralp Tip Dergisi 2013;5(3):5-8.
10. Özgüler M, Güngör LS, Kaygusuz T, Papila Ç. Elazı̆̆ Eğitim ve Araştırma Hastanesi Sağlık Çalışanlarında Hepatit A, Hepatit B, Kızamık ve Kızamıkçık Seroprevalansı. Klimik Dergisi 2016; 29(1): 10-4.

11. Bekçibaşı M, Üzel A. Sağllk çalışanlarında hepatit A, hepatit B, hepatit C ve HIV infeksiyonu seroprevelansi. ANKEM Derg2016;30:97-101.

12. Kepenek E. Hastane Çalışanlarında Hepatit B, Hepatit C ve HIV Virüsünün Seroprevalans Durumlarinin İncelenmesi. SelcukMed J 2017;33(3): 45-49.

13. Özçimen S, Kaçar F, Korkmaz F, Özcan M, Karakaş H, Sakız A. Konya EğitimAraştırma Hastanesi Sağlık Çalışanları'nın hepatit B ve hepatit C seroprevalansı. Eur J Basic MedSci2014;4:7-11

14. Halicioglu O, Akman SA, Tatar B, Atesli R, Kose S. Hepatitis A seroprevalence in children and adolescents aged 1-18 yearsamong a low socioeconomic population in Izmir, Turkey. Travel MedInfectDis2012;10:43-7

15. Budak Ș. İzmir Buca Seyfi Demirsoy Hastanesi İSGB(İsyeriSağlk ve Güvenlik Birimi) tarafindan yapılan çırak ve stajyerlerin işe giriş muayeneleri, seroloji testleri ve aşılama ișlemleri sonuçlarının değerlendirilmesi. Buca J Med2015;1:1-7.

16. Şahin A, Tekin A, Basmacı C, Uzun Kes N, Sönmez E. Hepatitis a seropositivity and characteristics among healthcare workers in a training and research hospital in Istanbul. MedSciDiscovery2016;3:296-300. 